\title{
Innovation to the performance evaluation process in a Puebla's government department by means of management tools strategies
}

\section{Innovación al proceso de evaluación del desempeño en un departamento gubernamental del estado de Puebla mediante el uso de herramientas de gestión estratégicas}

RAMIREZ-ROSAS, José†, ORTIZ-CARRANCO, Araceli, FLORES-ZAMORA, Jesús and LOZADALECHUGA, Jorge*

Universidad Politécnica de Puebla. Tercer Carril del Ejido, Serrano s/n, Cuanalá, 72640 Puebla, Pue.

ID $1^{\text {st }}$ Author: José, Ramirez-Rosas / ORC ID: 0000-0003-0664-3843, Researcher ID Thomson: L-9055-2018, CVU CONACYT ID: 502250

ID $1^{\text {st }}$ Coauthor: Araceli, Ortiz-Carranco / ORC ID: 0000-0001-7835-6339, Researcher ID Thomson: L-9246-2018, CVU CONACYT ID: 481086

ID $2^{\text {nd }}$ Coauthor: Jesús, Flores-Zamora / ORC ID: 0000-0003-2173-7792

ID $3^{\text {rd }}$ Coauthor: Jorge, Lozada-Lechuga / ORC ID: 0000-0003-1165-2007, Researcher ID Thomson: L-9205-2018, CVU CONACYT ID: 100439

DOI: $10.35429 /$ EJRP.2019.8.5.30.37

Received February 11, 2019; Accepted June 24, 2019

\begin{abstract}
The purpose of this work is to present an innovation to the performance evaluation process for a government department in the state of Puebla, which has as its main function the evaluation and monitoring of the scopes, goals and objectives of all the City Council dependencies and entities from the municipality of Puebla. The innovation presented is supported by the use of the Balanced ScoreCard (BSC) tool, automated by the use of strategic management software to provide timely, visual and executive monitoring of the results and scope of the strategic indicators proposed. In the development of this work, the following is proposed: the bases of the strategic planning of the government department in question, through the proposal for the BSC as well as, the elaboration of the strategic indicators of the same and ending with the simulation of the operability of the department already mentioned, in a software that supports the management of the BSC. The results showed a significant advance in the dependency's operations, reducing the time in the operative tasks in the evaluation process, deliverable executive documents for their valuation and making timely decisions for a constant improvement regarding the service provided.
\end{abstract}

Innovación, Desempeño, Cuadro de mando integral

\begin{abstract}
Resumen
El presente trabajo tiene como objetivo presentar una innovación al proceso de evaluación del desempeño para un departamento gubernamental en el estado de Puebla, el cual tiene como función principal la evaluación y seguimiento de los alcances, metas y objetivos de todas las dependencias y entidades del Ayuntamiento del municipio de Puebla. La innovación que se presenta está apoyada en el uso de la herramienta Balanced ScoreCard (BSC), automatizada mediante el uso de un software de gestión estratégica para darle seguimiento puntual, visual y ejecutiva a los resultados y alcances de los indicadores estratégicos planteados. En el desarrollo de este trabajo, se plantea lo siguiente: las bases de la planeación estratégica del departamento gubernamental en cuestión, pasando por la propuesta para el BSC así como, la elaboración de los indicadores estratégicos del mismo y finalizando con la simulación de la operatividad del departamento ya mencionado, en un software que apoya la gestión del BSC. Los resultados mostraron un avance significativo en las operaciones de la dependencia disminuyendo los tiempos en las tareas operativas en el proceso de evaluación, documentos ejecutivos entregables para su valoración y toma de decisiones oportunas para una mejora constante en cuanto al servicio prestado.
\end{abstract}

Innovation, Performance, Balanced scored card

Citation: RAMIREZ-ROSAS, José, ORTIZ-CARRANCO, Araceli, FLORESᄀ-ZAMORA, Jesús and LOZADALECHUGA, Jorge. Innovation to the performance evaluation process in a Puebla's government department by means of management tools strategies. ECORFAN Journal-Republic of Peru. 2019. 5-8: 30-37.

\footnotetext{
* Correspondence to Author (email: jorge.lozada@uppuebla.edu.mx)

$\dagger$ Researcher contributing first author.
} 


\section{Introduction}

The present work deals with the application of the BSC in a public body attached to the Government of the State of Puebla, through the innovation of a strategic management software in order to visualize the fulfillment of the proposed objectives, since, this administrative model has been functional in the entities with lucrative purposes; However, it is very useful to consider implementing it in non-profit organizations with the purpose of optimizing the budget granted.

This research is divided into five sections of which the first refers to the theoretical framework of the topic exposing the main currents of the BSC; the second section establishes the study methodology, emphasizing a practical cut; the third section presents the case study where the reference of the BSC proposal to the public body is made; in the end, the conclusions of the study will be explained as well as the results obtained from the study and finally the bibliographical references consulted from the research.

\section{Theoretical framework}

\section{Innovation}

\section{Etymology}

The word innovation comes from the Latin innovation, -ōnis, a term that derives from the term innovo, -are "make new", "renew", which is formed with in- "inward" and novus "new". (EcuRed, 2019)

\section{Definition}

The economist Schumpeter in his book the theory of Economic Development, defines innovation as follows:

"A process of creative destruction through which new technologies replace old ones that allows the economy and economic agents to evolve; It is the way in which the company manages its resources over time and develops competencies that influence its competitiveness". (EcuRed, 2019)

According to the Oslo manual (Oslo Manual, 2006) an innovation is:

\begin{abstract}
"The introduction of a new, or significantly improved, product (good or service), a process, a marketing method or an organizational method, in the internal practices of the company, the organization of the workplace or external relations"
\end{abstract}

Another definition for the term innovation is the following: "introduce novelties in a specific field of human knowledge that generates a social benefit".

\section{Process}

\section{Definition}

A relevant aspect in manufacturing and service organizations are the processes, because thanks to these, there can be continuous improvement promoting organizational innovation. It is important to start from a definition for the term process. For ISO 9000-2001 process is

"A set of mutually related or interacting activities, which transform input elements into results".

In the same way, (Ponjuan, Villardefrancos, \& León, 2005) defines process as:

"set of interrelated activities that transform input elements into output elements. Resources may include personnel, facilities, equipment, techniques, methods, information and others.".

An integrative definition for process is presented by (Medina, Nogueira, \& Hernández, 2009) "Orderly sequence of repetitive
activities that are carried out in the
organization by a person, group or
department, with the ability to
transform inputs (inputs) into
programmed outputs or results
(outputs) for a recipient (inside or
outside the company that has requested
and that are the clients of each process)
executed in an effective and efficient
way to obtain added value." 
Continuing with (Medina, Nogueira, \& Hernández, 2009) some characteristics of the processes are:

- The inputs and outputs can be described.

- People, groups or departments are involved in the realization of these.

- It has goals and objectives, answers the question What?

- It has indicators that can be visualized in graphic form for its measurement and evolution.

- They are dynamic: they depend on resources, skill and motivation, as well as knowledge to generate the desired result.

\section{Types of innovation}

Following the Oslo Manual (Oslo Manual, 2006), it proposes four main types of innovation: product, process, marketing and organization. For the purposes of this work, only the definition of process innovation will be addressed. A process innovation is:

"The introduction of a new, or significantly improved, production or distribution process. This implies significant changes in techniques, materials and / or software.".

It is worth mentioning that process innovations can aim to reduce unit production or distribution costs, improve quality or distribute new or significantly improved products.

The Oslo manual is very precise in establishing that process innovations include new or significantly improved techniques, equipment and software, as well as the introduction of a new, or significantly improved, information and communication technology (ICT) $)$ is a process innovation if it is intended to improve the quality of a basic support activity.

\section{Balanced Scorecard or Integral Scorecard}

When contemplating implementing a BSC or Balanced Scorecard it is very important to have a clearly defined mission, vision and values organizations, to elaborate or develop a strategy that is consistent with what the nature of the company and the way in which it visualizes in a Future (Herrera, Martín, \& Frías, 2019)

The Balanced Scorecard translates the mission and strategy of the organization into a comprehensive scenario that provides performance measures for strategic management decisions (Estupiñan, 2010).

The balanced scorecard includes four perspectives which have the same importance within an organization, these four perspectives are:

- Financial Perspective: economic measures that are reflected by the actions taken in organizations

- Customer Perspective: Identifies the customer and the market segment in each business unit, as well as the performance indicators for each business unit referring to the organization.

- Perspective of internal processes: Measures the "critical internal processes in which the organization must excel".

- Learning and Growth: Measures the infrastructure that the organization must build to create a long growth team (Kaplan \& Norton, 2008).

\section{Strategic map}

Strategic maps are the most important conceptual contribution of the Balanced Scorecard; They provide support to understand the coherence between the strategic objectives and allow a simple and very graphic visualization of the company's strategy (Fernández, 2001). The strategic map reflects the chain of cause-effect relationships of the strategy to be developed and graphically shows the activities necessary for the organization to achieve the vision proposed (Yetano, 2005). The strategic map helps assess the importance of each objective, because it shows them classified by perspective. (Fernández, 2001). 


\section{Key Performance Indicator}

A KPI, the English Key Performance Indicator, known as the Key Performance Indicator, (or also the Key Performance Indicator) is a measure of the level of performance of a process; The value of the indicator is directly related to a target set in advance. It is usually expressed as a percentage (Jackson, 2015).

According to (Muñoz, 2009) an indicator can be defined as a variable whose control provides accurate information through periodic comparisons. The indicators can be financial or non-financial, they are used to measure the degree of compliance with the previously established objectives, they are usually expressed as a percentage; They are generally considered in the strategic plan of an organization. (What does KPI mean ?, 2017).

It is very important to clarify what it is that you want to measure, it must be consistent with the objectives set. Some essential indicators are those related to customers, product quality, financial health and teamwork success (Sánchez, Bayona, Prado, \& Mendoza, 2019)

\section{ICT}

Currently, in organizations the use of Information and Communication Technologies (ICT) is a differentiating factor, executives who make use of ICT in the strategic management process can make better decision making, because they have information reliable and in real time (Cotrina, and others, 2019).

In fact, (Aguilera \& Riascos, 2009) mention that in the strategic analysis phase a large amount of information can be generated, at two specific moments: when the knowledge that the different experts of the organization have is abstracted and later in the analysis of the information collected.

In the same way, when using management control tools, it is important that executives can help themselves with software designed for this purpose, so that the visualization of processes, indicators and their monitoring are integral. So too, the C.E.O. You can help with computer tools such as: process flow diagram, statistical software or decision support systems (Domínguez \& Gaytán, 2019).

\section{Methodology to be developed}

The present study has been based on a methodology called Action Research (Yin, 2014) which cyclically seeks to diagnose an organizational problem and plan its solution, it is mixed cut because quantitative and qualitative data will be collected that will allow the proposed indicators of the BSC, participatory type because the research considered the people of the study subject in order to solve the practical problems (Torres, Fernández, Espinoza, \& Cabrera, 2019). On the other hand, the methodology developed to achieve the objectives of the research was carried out based on the following guidelines.

a) A diagnosis was carried out by applying an exploratory questionnaire to obtain results to be analyzed to develop the BSC indicators.

b) Based on the above, a SWOT analysis was carried out to determine that in the end the MAFE matrix will be carried out in order to determine the strategy to be attacked.

c) In conjunction with the above, the business philosophy proposal was made based on the BSC model being guided through the mission of the organization.

d) From the above, the next step was elaborated, which was the formulation of BSC indicators.

e) Subsequently, the BSC mapping proposal was made.

To select the strategic management software tool, the following was done.

a) The different tools that could be used to export the BSC model to the computer system were identified.

b) The most appropriate tool was selected based on the needs of the organization.

c) So that, finally, the computer tool with the BSC model was implemented and thus obtain results. 


\section{Case study}

The study presented was conducted in a government department in the state of Puebla where an exploratory questionnaire was designed to be self-applied; this with the objective of determining the strategy through the analysis of the SWOT and MAFE matrices as described in tables number 1 and 2.

\begin{tabular}{|c|c|}
\hline ths & Opportunities \\
\hline $\begin{array}{l}\text { 1. Training and ongoing } \\
\text { advice are provided. } \\
2 \text {. The SEDEM, is } \\
\text { recognized at local, } \\
\text { national and international } \\
\text { level } \\
\text { The collaborators of the } \\
\text { D.E. have a bachelor's or } \\
\text { postgraduate degree. }\end{array}$ & $\begin{array}{l}\text { 1. Possible reduction of } \\
\text { time in receiving } \\
\text { information (quarterly). } \\
\text { 2. Possible reduction of } \\
\text { time in obtaining results } \\
\text { (currently } 60 \text { days). } \\
\text { 3. Executive reports can } \\
\text { be generated } \\
\text { automatically. (Office). } \\
4 \text { Coordinated work } \\
\text { could be carried out with } \\
\text { national and international } \\
\text { organizations. }\end{array}$ \\
\hline $\begin{array}{l}\text { Weaknesses } \\
\text { 1. Times of elaboration of } \\
\text { prolonged reports }(60 \\
\text { days). } \\
\text { 2. Amount of information } \\
\text { exceeds the capacity of } \\
\text { the department ( } 5 \text { people). } \\
\text { 3. Little training is } \\
\text { received within the D.E. } \\
\text { (once a year). }\end{array}$ & $\begin{array}{l}\text { Threats } \\
\text { 1. Possible modifications } \\
\text { to methodologies, } \\
\text { programming processes, } \\
\text { evaluation and budgeting } \\
\text { by the higher levels. } \\
\text { 2. Budget reduction by the } \\
\text { government. } \\
\text { 3. Possible delays to the } \\
\text { activities of the } \\
\text { 4. D.E for external errors }\end{array}$ \\
\hline
\end{tabular}

Table 1 SWOT matrix of the organization

Source: elaboration based on (IMPLAN, 2019)

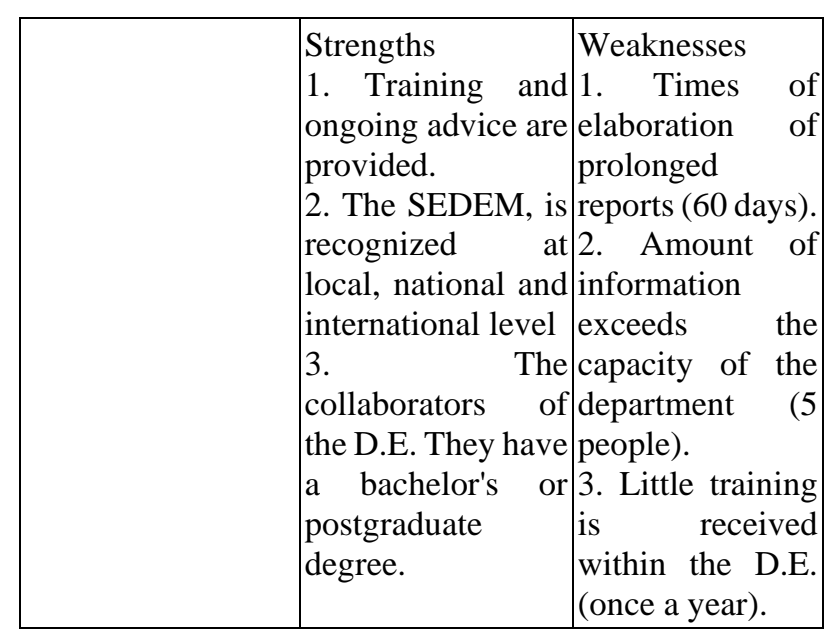

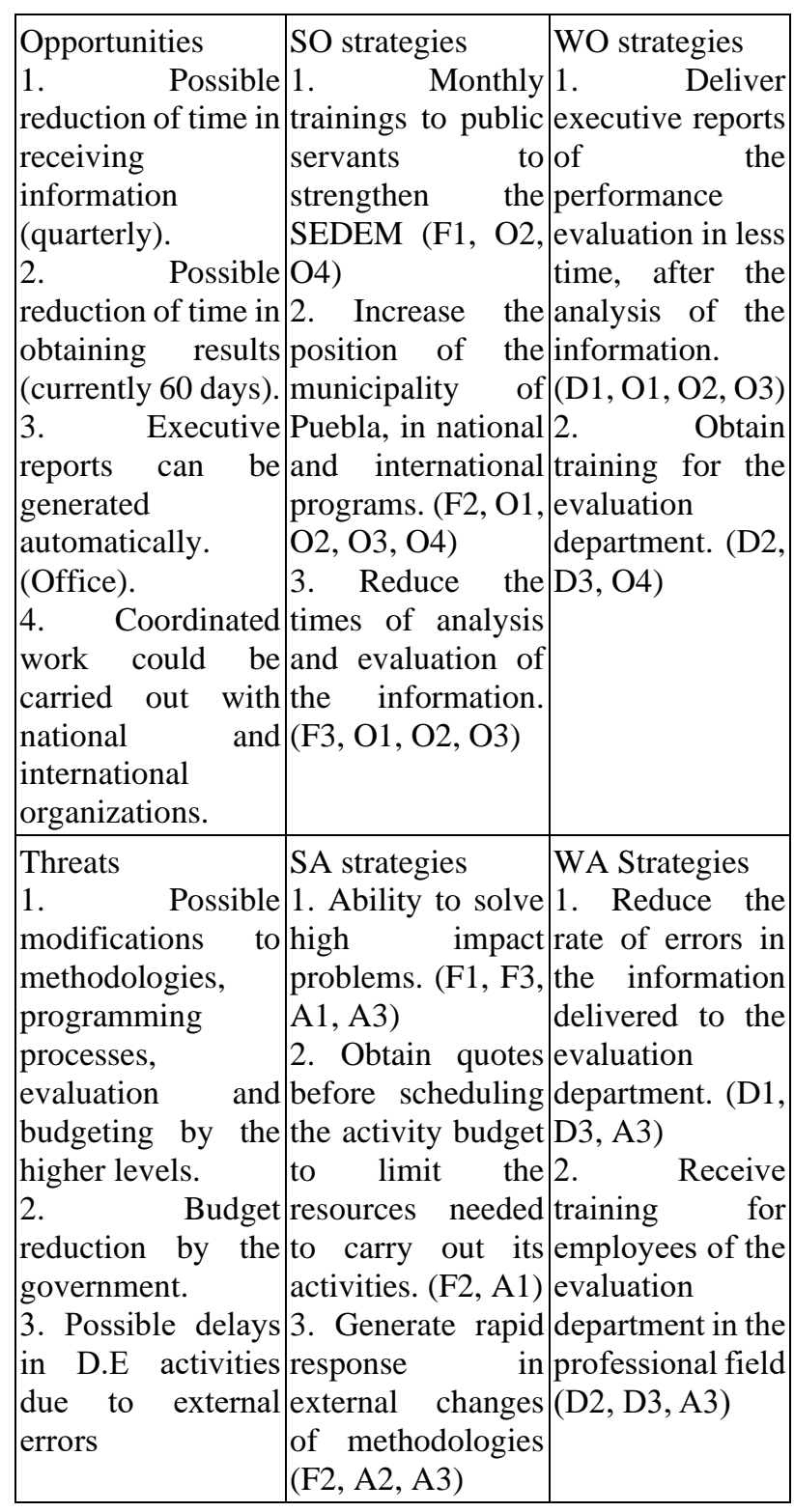

Table 2 MAFE matrix of the organization Source: elaboration based on (IMPLAN, 2019)

The BSC model focuses on financial perspectives, internal processes, growth and development and clients (Kaplan, 2008), based on the entity's business philosophy, so the mission and vision proposal that was followed It is described.

\footnotetext{
"Vision: To be an evaluation department of the public sector that is a national reference, following up on the Performance Evaluation System in an effective, efficient, transparent and honest way".
} 
"Mission: Periodically evaluate and monitor the municipal development plan, as well as the performance evaluation system of the municipality of Puebla, encompassing the different agencies and entities based on government regulations.".

According to the above, the strategic indicators were constructed using the signalization of the colors indicating green as something correct, yellow being defined as alert and red as an indicator of a danger state, proposing the BSC model for the department which is described in table number 3 .

\begin{tabular}{|c|c|c|c|}
\hline Indicators & Satisfactory & Preventive & Unsatisfactory \\
\hline $\begin{array}{l}\text { Obtain at least } 3 \\
\text { quotes before } \\
\text { programming } \\
\text { the activity } \\
\text { budget to limit } \\
\text { the necessary } \\
\text { resource. }\end{array}$ & 3 & 2 & $0-1$ \\
\hline $\begin{array}{l}\text { Provide } 1 \\
\text { monthly training } \\
\text { to public } \\
\text { servants to } \\
\text { strengthen } \\
\text { performance } \\
\text { evaluation } \\
\text { system. }\end{array}$ & $100 \%-90 \%$ & $89 \%-80 \%$ & $<80 \%$ \\
\hline $\begin{array}{l}\text { Reduce by } 20 \% \\
\text { per year the } \\
\text { errors in the } \\
\text { information } \\
\text { delivered to the } \\
\text { evaluation } \\
\text { department } \\
\text { based on the } \\
\text { training } \\
\text { provided to the } \\
\text { workers of the } \\
\text { municipality of } \\
\text { Puebla. }\end{array}$ & $\geq 20 \%$ & $18 \%-15 \%$ & $<15 \%$ \\
\hline $\begin{array}{l}\text { Achieve at least } \\
86 \% \text { in the } \\
\text { "Diagnosis on } \\
\text { the progress in } \\
\text { the } \\
\text { implementation } \\
\text { of the PbR- } \\
\text { SED" of the } \\
\text { SHCP }\end{array}$ & $85.5 \%-86 \%$ & $\begin{array}{l}84.1 \%- \\
85.5 \%\end{array}$ & $<84 \%$ \\
\hline $\begin{array}{l}\text { Reduce to } 42 \\
\text { days, the } \\
\text { analysis and } \\
\text { evaluation times } \\
\text { of the } \\
\text { performance } \\
\text { information of } \\
\text { the municipality } \\
\text { of Puebla. (use } \\
\text { of software) }\end{array}$ & 42 - 47 days & $\begin{array}{l}48-53 \\
\text { days }\end{array}$ & $>53$ days \\
\hline
\end{tabular}

Table 3 BSC mapping proposed to the organization

However, to achieve the parameters described above, the strategies are described in the four perspectives of the BSC model.
For the indicator of the financial perspective, it was proposed to improve the use of the budget granted to this department based on the quotation before requesting its budget, as described in Table 4.

\section{General objective Indicators}

Improve the use of the Obtain at least 3 quotes before budget as a management programming the activity budget tool. to limit the necessary resource

Table 4 Financial Perspective Strategy Source: elaboration based on information from (IMPLAN, 2019)

In the client perspective section, it was proposed to take as reference the information received by the department based on the training of public servants, which is described in table number 5 .

\begin{tabular}{|c|c|}
\hline $\begin{array}{c}\text { General } \\
\text { objective }\end{array}$ & Indicators \\
\hline $\begin{array}{l}\text { Improve the } \\
\text { information } \\
\text { received from the } \\
\text { other } \\
\text { departments of } \\
\text { the town hall of } \\
\text { Puebla, to } \\
\text { generate the } \\
\text { performance } \\
\text { evaluation. }\end{array}$ & $\begin{array}{l}\text { Provide } 1 \text { monthly training to } \\
\text { public servants to strengthen the } \\
\text { Performance Evaluation System. } \\
\text { Reduce by } 20 \% \text { per year the } \\
\text { errors in the information delivered } \\
\text { to the evaluation department } \\
\text { based on the training provided to } \\
\text { the workers of the municipality of } \\
\text { Puebla. }\end{array}$ \\
\hline
\end{tabular}

Table 5 Customer Perspective Strategy

Source: elaboration based on information from (IMPLAN, 2019)

For the perspective of internal processes, it is intended to reduce work times in terms of the realization of deliverables by the department, as described in table number 6 .

\begin{tabular}{|l|l|}
\hline \multicolumn{1}{|c|}{$\begin{array}{c}\text { General } \\
\text { objective }\end{array}$} \\
\begin{tabular}{|l} 
Reduce \\
work times
\end{tabular} & $\begin{array}{l}\text { Andicators } \\
\text { "Diagnosis on the progress in the } \\
\text { implementation of the PbR-SED" of } \\
\text { the SHCP } \\
\text { Reduce to 42 days, the analysis and } \\
\text { evaluation times of the performance } \\
\text { information of the municipality of } \\
\text { Puebla. } \\
\text { Deliver 26 executive reports of the } \\
\text { evaluation of the performance of the } \\
\text { municipality of Puebla 30 days after } \\
\text { receiving the information. }\end{array}$ \\
\hline
\end{tabular}

Table 6 Internal Process Perspective Strategy

Source: development based on information from (IMPLAN, 2019)

RAMIREZ-ROSAS, José, ORTIZ-CARRANCO, Araceli, FLORESᄀZAMORA, Jesús and LOZADA-LECHUGA, Jorge. Innovation to the performance evaluation process in a Puebla's government department by means of management tools strategies. ECORFAN Journal-Republic of Peru. 2019 
With regard to the perspective of learning and growth, the aim is to improve the capacities of employees through constant training schemes, focused on their daily work, which is described in Table 7.

\begin{tabular}{|l|l|}
\hline \multicolumn{1}{|c|}{ General objective } & \multicolumn{1}{c|}{ Indicators } \\
\hline $\begin{array}{l}\text { Improve the skills } \\
\text { of the employees } \\
\text { of the Evaluation } \\
\text { Department. }\end{array}$ & $\begin{array}{l}\text { Obtain 4 annual trainings for } \\
\text { the D.E. on performance } \\
\text { evaluation issues. }\end{array}$ \\
& $\begin{array}{l}\text { Obtain 1 annual training for the } \\
\text { D.E. in professional matters. }\end{array}$ \\
\hline
\end{tabular}

Table 7 Learning and growth perspective strategy Source: elaboration based on information from (IMPLAN, 2019)

Once the relevant indicators were developed for each perspective, the management software was selected to support the monitoring of the indicators in the BSC.

The criteria chosen for the selection of the tool were the following: 1) The language 2) Free access for the trial period without the use of a credit card to the tool 3) No computer skills are needed to manipulate the software.

In this way, it was possible to follow up the indicators of the D.E. for its continuous assessment by managers, as well as support for timely decision making regarding the programming of the annual activities of this department. The procedure followed for the use of the software is as follows:

a) A user was registered on the platform of said software, in order to access the free trial period.

b) Creation of projects Once the account with which the software will be used is created, we proceed to enter the platform, which will allow us to create new projects or strategic maps, modify or eliminate existing ones.

c) Integration of strategic indicators. Once within the new or existing project, the information of the indicators is loaded together with its general objective, it should be mentioned that these were previously proposed here only loaded into the software for monitoring. d) Indicator settings In this section, the appropriate adjustments were made to each indicator, such as its goal or scope, its starting point, its evaluation parameters and the specific signaling ranges for its visualization in more detail.

e) Monitoring of the indicators. To closely monitor the scope of the strategic objectives and indicators of the ED, the software provides us with some exposure options, which will depend on the person interested in the information to obtain the results regarding the progress and performance of each of the activities highlighted to meet your final goal.

\section{Conclusions and Results}

The results obtained were aligned with the objectives set out in the present study. The SWOT analysis and the MAFE matrix were prepared, so the proposal of the strategic philosophy was also developed and the design of the BSC for the D.E. In the same way, a strategic management software for the manipulation of the BSC information of the organization was implemented so that the indicators can be monitored immediately and the decision-making process is expedited.

Derived from the above, an innovation was generated in the process of performance evaluation from a strategic point of view due to the use of the BSC to monitor the implemented strategy; and from the technical perspective, the innovation is due to the implementation of a business management software to automatically have the available information and improve the quality in the measurement of the objectives set by the entity.

Finally, it has been possible to indicate that this type of business strategies is not limiting for profit-making entities, but that, in turn, they work for those public organizations because it is about optimizing processes, improving customer satisfaction. client and improve the management of the budget granted. 


\section{References}

¿Qué significa KPI? (15 de 09 de 2017). Recuperado el 4 de 09 de 2019, de https://www.grupokpi.com.co/singlepost $/ 2017 / 09 / 15 / \%$ C2\%BF-QUE-SIGNIFICAKPI

Aguilera, A., \& Riascos, S. (2009). Direccionamiento estratégico apoyado en las TIC. Estudios gerenciales, 127-143.

Cotrina, J., Milón, G., Magnolia, P., Ruiz, J., Coral, V., \& Ángel, M. (2019). Estudio de caso: aplicación del Modelo Intellectus y aproximación a la gestión del capital intelectual en una empresa industrial y comercial de la ciudad de Popayán-Cauca en el II semestre de 2018. Fortalecimiento de la gestión estratégica de las facultades de la UNSM-T en el marco de la acreditación universitaria.

Domínguez, J., \& Gaytán, J. (2019). Sistema único integrado de gestión: calidad, ambiente, seguridad y salud TEUKEN BIDIKAY. Latinoamericana de investigación en organizaciones, ambiente y sociedad. , 10 (4).

EcuRed. (3 de 09 de 2019). Obtenido de https://www.ecured.cu/Innovaci\%C3\%B3n

Estupiñan, R. (2010). Análisis financiero y de gestión.

Fernández, A. (2001). El balanced Scorecard ayudando a implantar la estrategia. Antiguos alumnos, 31-42.

Herrera, N., Martín, G., \& Frías, M. J. (2019). Propuesta de un sistema de evaluación de desempeño en una empresa constructora.

Jackson, T. (5 de 03 de 2015). Clear Point Strategy. Obtenido de https://www.clearpointstrategy.com/18-keyperformance-indicators/

Kaplan, R., \& Norton, D. (2008). Cuadro de Mando Integral.

Manual de Oslo. (2006). 3. España: EUROSTAT /OCDE. Recuperado el 03 de 09 de 2019
Medina, A., Nogueira, D., \& Hernández, A. (2009). Relevancia de la Gestión por Procesos en la Planificación Estratégica y la Mejora Continua . Eídos, 65-72.

Muñoz, E. (2009). Cuadro de Mando Integral (Balanced Scorecard) para la gestión bibliotecaria: pautas para una aplicación. Investigación bibliotecológica, 105-126.

Ponjuan, G., Villardefrancos, M. d., \& León, M. (2005). Principios y métodos para el Mejoramiento Organizacional . La Habana: Félix Varela.

Sánchez, C., Bayona, B., Prado, L., \& Mendoza, E. (2019). Innovación y tecnología en el tercer sector paradigmas y desafíos . Colombiana de tecnologías de avanzada (RCTA), 1 (33).

Torres, F., Fernández, V., Espinoza, M., \& Cabrera, R. (2019). El modelo tetrahelice para el desarrollo de innovación tecnologíca. EDUCATECNOCIENCIA, 21 (22).

Yetano, A. (2005). El cuadro de mando integral (balanced scorecard) en la Administración Local. Auditoría y gestión de fondos públicos., $39-46$.

Yin, R. (2014). Case Study Research Design and Methods. Canadian Journal of Program Evaluation, 282. 